\title{
Index
}

\section{Volume 46, 2002}

\section{Compiled by Edward Swanson}

General Procedures Used in Compiling the Index

The following types of entries are included:

a. authors - of articles, reviews, and letters

b. titles - of articles and of articles about which letters were published

c. subjects—of articles and of books reviewed

Subject entries for individuals are identified by "(about)"; letters are identified by "(c)".

Reviews are indexed by name of reviewer and by subject of the work reviewed, identified by " $(r)$ ". They are also listed by title under the heading "Books reviewed".

Entries are arranged word by word following the "file-as-spelled" principle. Numbers are arranged before alphabetical characters; acronyms without internal punctuation are arranged as words.

Subject headings are based on: ASIS Thesaurus of Information Science and Librarianship, $2 d$ ed., edited by Jessica L. Milstead (Medford, N.J.: Published for the American Society for Information Science by Information Today, Inc., 1998).

Paging of Volume 46:

Pages 1-36 = Number 1 (January)

Pages $37-76=$ Number 2 (April)

Pages 77-112 = Number 3 (July)

Pages 113-164 = Number 4 (October)

\section{A}

Academic librarians

Core competencies: 11-22

Adams, David L.: 11-22

ALCTS, see Association for Library

Collections \& Technical Services

"ALCTS Contact Information" 94

"ALCTS Leaders" 95

Association for Library Collections \&

Technical Services

Directories: 94,95

Officers of: 95

Association for Library Collections \&

Technical Services, Education Policy

Statement: 11-22

Authority files

Of subject headings: 92, 97-102

Use of World Wide Web in creating: $79-84,87-91$

\section{B}

Bell, Daniel: 50-61

Bibliographic control

Congresses: 32-33 (r)
Bibliographic entities

Relationships among: 150-59

Bicentennial Conference on Bibliographic Control for the New Millennium: 32-33 $(r)$

Books reviewed

Copyright in Cyberspace: Questions and Answers for Librarians

(Hoffmann): 34-35

The Invisible Web: Uncovering Information Sources Search Engines Can't See (Sherman and Price): $74-75$

The Map Library in the New Millennium (Parry and Perkins, eds.): $35-36$

Maps and Related Cartographic Materials Cataloging, Classification, and Bibliographic Control (Andrew and Larsgaard, eds.): $75-76$

Proceedings of the Bicentennial Conference on Bibliographic Control for the New Millennium (Sandberg-Fox, ed.): 32-33
Seymour Lubetzky: Writings on the Classical Art of Cataloging (Lubetzky; Svenonius and McGarry, comps. and eds.): $72-73$

Sorting Out the Web: Approaches to Subject Access (Schwartz): 33-34

Subject Headings in Online Catalogs (Olson and Boll): 73-74

Borneman, Dea: 11-22

Brooklyn College: 62-71

\section{C}

Castells, Manuel: 50-61

Catalogers

Training of: 11-22

"Cataloging Efficiency and Effectiveness" 23-31

Cataloging: $72-73(r)$

Analysis: 23-31

Effectiveness in: 23-31

Efficiency in: 23-31

Study and teaching: 11-22 
"The Challenge of Building Multilingual Collections in Canadian Public Libraries" 115-36

"Characteristics of Resources Represented in the OCLC CORC Database" 39-49

Collection development: 50-61

Connell, Tschera Harkness: 39-49

Cooperative cataloging: 105-10

"Cooperative Cataloging, Vendor Records, and European Language Monographs" 105-10

Copyright

Of electronic resources: 34-35 $(r)$

CORC, see OCLC Online Computer Library Center, Cooperative Online Resource Catalog

Core competencies

For academic librarians: 11-22

Dali, Keren: 115-36

Digital scanning

For acquisitions purposes: 3-10

For preservation purposes: $3-10$

Dilevko, Juris: 115-36

\section{E}

Effectiveness

In cataloging: 23-31

Efficiency

In cataloging: 23-31

Electronic resources

Copyright of: 34-35 $(r)$

Ellero, Nadine P.: 79-91

European languages materials Cataloging: 105-10

\section{$\mathbf{F}$}

"FRBR: Functional Requirements for Bibliographic Records: Application of the Entity-Relationship Model to Humphrey Clinker" 150-59

Functional Requirements for Bibliographic Records: 150-59

Fyffe, Richard: 50-61

\section{G}

“'Garbage' In, 'Refuse and Refuse Disposal' Out: Making the Most of the Subject Authority File in the OPAC" 92, 97-102

Giddens, Anthony: 50-61

Gregory, Vicki L.: 34-35 (r)

\section{H}

Holley, Robert P.: 138-49

Horn, Marguerite E.: 92, 97-102

Hostage, John: 33-34 (r)

\section{I}

IFLA Study Group on the Functional Requirements for Bibliographic Records: $150-59$

"Instructions to Authors" 160-61

Internet

Searching: 74-75 $(r)$

Inventory

Of library collections: 62-71

"Inventory at Brooklyn College, 1998-1999: An Original Method" 62-71

\section{J}

Johnson, Kay G.: 75-76 (r)

\section{K}

Kellerman, L. Suzanne: 3-10

Kellsey, Charlene: 105-10

\section{L}

Letarte, Karen M.: 11-22

Library collections

Inventorying: 62-71

Lubetzky, Seymour: 72-73 (r)

\section{M}

Manoff, Michael: 35-35 (r)

Map libraries: 35-36 $(r)$

Maps

Cataloging: 75-76 $(r)$

Classification: 75-76 $(r)$

McCain, Cheryl: 23-31

Multilingual library materials Acquisition: 115-36

OCLC Online Computer Library Center: 105-10

OCLC Online Computer Library Center, Cooperative Online Resource Catalog

Web resources in: 39-49

O’Neill, Edward T.: 150-59

Online public access catalogs, see OPACS
OPACS

Subject headings in: 92, 97-102; $73-74,(r)$

"Out-of-Print Digital Scanning” 3-10

Out-of-print materials

Acquistions: 3-10

Preservation: $3-10$

"Panning for Gold: Utility of the World Wide Web for Metadata and Authority Control in Special Collections" 79-91

Penn State University Libraries: 3-10

Philip S. Hench Walter Reed Yellow Fever Collection (University of Virginia): 79-84, 87-91

Prabha, Chandra: 39-49

"Practitioner Perspectives on Cataloging Education for Entry-Level Academic Librarians" 11-22

Preservation of library materials: 3-10

Public libraries

Canada: 115-36

Multilingual materials in: 115-36

\section{$\mathbf{R}$}

"Répertoire de Vedettes-matière de l'Université Laval Library, 1946-92: Francophone Subject Access in North America and Europe" 138-49

Research Libraries Network, see RLIN

RLIN: 105-10

Rohdy, Margaret: 32-36, 72-76

\section{S}

Scholarly publishing: 50-61

Search engines: 74-75 $(r)$

Shorten, Jay: 23-31

Smollett, Tobias George. The Expedition of Humphry Clinker: 150-59

Special collections

Cataloging: 79-84, 87-91

Subject access

To World Wide Web: 33-34 (r)

Subject headings

Authority files of: 92, 97-102

Canada: 138-49

French language: 138-49

In OPACS: 73-74 $(r)$

Subject searching In OPACS: 92, 97-102

Swanson, Edward: 161-63 
$\mathbf{T}$

"Technological Change and the Scholarly Communications Reform

Movement" 50-61

Turvey, Michelle R.: 11-22

\section{U}

Université Laval. Bibliothèque.

Répertoire des vedettes-matière de la Bibliothèque de l'Université

Laval: 138-49
University of Virginia. Claude Moore Health Sciences Library: 79-84, 87-91

\section{V}

Vendor records

In bibliographic databases: 105-10

\section{W}

Web sites, see World Wide Web

Wild, Judith W.: 62-71

\author{
Wool, Gregoy: 74-75 (r) \\ World Wide Web \\ Access to: 39-49 \\ In authority control: 79-84, 87-91 \\ Searching: 33-34 $(r), 74-75(r)$
}

\section{Y}

Yee, Martha M.: 32-33 (r), 72-73(r)

Young, J. Bradford: 73-74 $(r)$ 